\title{
A mikro-RNS-ek jelentősége szisztémás autoimmun betegségek kialakulásában
}

\author{
Jámbor Ilona* . Szabó Krisztina dr.* - Zeher Margit dr. ${ }^{\dagger}$ - Papp Gábor dr. \\ Debreceni Egyetem, Általános Orvostudományi Kar, Belgyógyászati Intézet, \\ Klinikai Immunológiai Tanszék, Debrecen
}

\begin{abstract}
A mikro-RNS-ek (miRNS) 18-25 nukleotid hosszúságú, egyszálú, endogén, nem kódoló kis RNS-ek, melyek fontos szerepet játszanak a génexpresszió poszttranszkripcionális szinten történő finomhangolásában. A fehérjét kódoló gének körülbelül 90\%-a áll a miRNS-ek regulációs hatása alatt, melyek így kulcsszerepet játszanak különböző biológiai folyamatokban, többek között a sejtfejlődés, -proliferáció, -differenciálódás, -apoptózis és az immunhomeosztázis szabályozása során. Egyes miRNS-ek expressziójában bekövetkező változások hozzájárulhatnak számos kórkép, köztük szisztémás autoimmun betegségek kialakulásához is. A jelen tanulmányban összefoglaljuk a miRNS-ek biogenezisét, az immunrendszer szabályozásában betöltött szerepüket, illetve áttekintjük a legújabb kutatási eredményeket szisztémás lupus erythematosusban, primer Sjögren-szindrómában, rheumatoid arthritisben és szisztémás sclerosisban. A jövőben a miRNS-ek nemcsak mint biomarkerek segíthetnek majd a diagnózis és prognózis meghatározásában, hanem potenciális terápiás célpontokként is alkalmazhatók lehetnek az autoimmun betegségek modern terápiájában. Orv Hetil. 2019; 160(15): 563-572.
\end{abstract}

Kulcsszavak: mikro-RNS, primer Sjögren-szindróma, szisztémás lupus erythematosus, rheumatoid arthritis, szisztémás sclerosis

\section{The importance of microRNAs in the development of systemic autoimmune disorders}

\begin{abstract}
MicroRNAs (miRNAs) are 18-25 nucleotide long, single stranded, endogenous, non-coding small RNAs playing an important role in regulating gene expression at posttranscriptional level. miRNAs control approximately $90 \%$ of protein-coding genes, and play a central role in various biological processes including immune cell lineage commitment, differentiation, proliferation, apoptosis and maintenance of immune homeostasis. Changes in the expression of certain miRNAs may lead to the development of many diseases, including systemic autoimmune diseases. In this study, we summarize the biogenesis of miRNAs, their role in regulation of the immune system, and review the latest research findings in systemic lupus erythematosus, primary Sjögren's syndrome, rheumatoid arthritis and systemic sclerosis. In the future, miRNAs may help not only in establishing diagnosis and prognosis but potentially serve as targets for modern therapeutic approaches in autoimmune diseases.
\end{abstract}

Keywords: microRNA, primary Sjögren's syndrome, systemic lupus erythematosus, rheumatoid arthritis, systemic sclerosis

Jámbor I, Szabó K, Zeher M, Papp G. [The importance of microRNAs in the development of systemic autoimmune disorders]. Orv Hetil. 2019; 160(15): 563-572.

Beérkezett: 2018. november 5.; elfogadva: 2018. november 21.)

A Szerkesztőség felkérésére készült tanulmány.

\section{Rövidítések}

$\alpha \mathrm{SMA}=\alpha$-simaizom aktin; $\mathrm{AHR}=($ aryl hydrocarbon receptor $)$ arilhidrokarbon-receptor; ARNT $=($ AHR nuclear translocator) AHR nukleáris transzlokátor; $\mathrm{DC}=($ dendritic cell $)$ dendritikus sejt; DGCR8 = $($ DiGeorge syndrome critical region gene 8) DiGeorge-szindróma kritikus régió 8; ECM = extracelluláris mátrix; eGFR = (estimated glomerular filtration rate $)$ becsült glomerularis filtrációs ráta; $\mathrm{EGM}=$ (extraglandular manifestation) extraglandularis manifesztáció; FADD $=($ FAS associated death domain) Fas-fehérjéhez kötődő haláldomén; 
FLS = (fibroblast-like synoviocytes $)$ fibroblastszerü synoviocyta; Fox $=$ forkhead box; Foxol $=($ forkhead box Ol $)$ forkhed box fehérje Ol; GADD $45 \alpha=$ (growth arrest and DNA damage-45 alpha) növekedést megállító és DNS sérülést indukáló $45 \alpha$ fehérje; $\mathrm{GC}=$ germinális centrum; IFN $\beta=$ interferonbéta; IFN $\gamma=$ interferon-gamma; IKK $\varepsilon=($ inhibitor- $\kappa \mathrm{B}$ kinase $\varepsilon)$ inhibitor-kappa-B-kináz-epszilon; ILl = interleukin- 1 ; IRAK = (interleukin-1 receptor-associated kinase) interleukin-1 receptorhoz kapcsolt kináz; IRF5 = (interferon regulatory factor 5) interferon regulatorikus faktor; $\mathrm{LN}=$ lupus nephritis; MALT = (mucosa-associated lymphoid tissue) nyálkahártya-asszociált lymphoid szövet; MAPK = mitogénaktivált proteinkináz; MCPl $=($ monocyte chemoattractant protein 1$)$ monocita kemoattraktáns protein- 1 ; miRNS $=($ microRNA $)$ mikro-RNS; MMPl $=($ matrix metalloproteinase 1$)$ mátrix metalloproteináz- $1 ; \mathrm{mRNS}=($ messenger RNA) hírvivő $\mathrm{RNS} ; \mathrm{NF} \kappa \mathrm{B}=$ nukleárisfaktor-kappa-B; $\mathrm{NK}=$ (natural killer) természetes ölősejt; $\mathrm{OA}=$ osteoarthritis; $\mathrm{PBMC}=$ (peripheral blood-derived mononuclear cell) perifériás vér mononukleáris sejt; PCNA = (proliferating cell nuclear antigen) proliferáló sejtmagantigén; pre-miRNS $=$ prekurzor miRNS; PRR $=($ pattern recognition receptor) mintázatfelismerő receptor; pSS = (primary Sjögren's syndrome) primer Sjögren-szindróma; PTEN = (phosphatase and tensin homolog) foszfatáz- és tenzinhomológ; RA = rheumatoid arthritis; RISC $=$ (RNA-induced silencing complex $)$ RNS indukálta csendesítő komplex; RNS = ribonukleinsav; SLE $=$ (systemic lupus erythematosus) szisztémás lupus erythematosus; $\mathrm{SSc}=$ (systemic sclerosis) szisztémás sclerosis; TGF $\beta 1=$ (transforming growth factor-beta 1 ) transzformáló növekedési faktor-beta- 1 ; TIMPl = (tissue inhibitor of matrix metalloproteinase) szöveti metalloproteinázgátló; TLR = (Toll-like receptor) Toll-szerü receptor; $\mathrm{TNF}=$ (tumor necrosis factor) tumornekrózis-faktor; TNFR $=$ (tumor necrosis factor receptor) TNF-receptor; TRAF $=$ (tumor necrosis factor receptor associated factor) TNF-receptorhoz asszociált faktor; $\mathrm{uPA}=$ (urokinase plasminogen activator) urokináz típusú plazminogénaktivátor; $3^{\prime} \mathrm{UTR}=\left(3^{\prime}\right.$ untranslated region $)$ nem transzlálódó szakasz a 3 ' végen

A mikro-RNS-ek (miRNS) egyszálú, endogén, nem kódoló, 18-25 nukleotid hosszúságú RNS-ek, melyek a génexpresszió poszttranszkripcionális szabályozásában játszanak meghatározó szerepet. A génkifejeződés úgynevezett finomhangolását segítik elő azáltal, hogy az adott messenger RNS (mRNS)-hez kötődve megakadályozzák az arról történő fehérjeátíródást. A szabályozás komplexitását mutatja, hogy egy miRNS több mRNS-t is szabályozhat, illetve egy adott mRNS több miRNS szabályozása alatt is állhat. Jelenlegi ismereteink alapján a fehérjét kódoló gének körülbelül 90\%-a áll a miRNS-ek regulációs hatása alatt, melyek így kritikus szerepet játszanak különböző biológiai folyamatokban a sejtfejlődés, -proliferáció, -differenciálódás, -apoptózis és stresszválasz során. Egyes miRNS-ek expressziójának megváltozását számos kórképben, köztük különféle daganatokban és autoimmun kórképekben is leírták, és az eddigi vizsgálatok alapján ezek a specifikus eltérések fontos szerepet játszhatnak az adott betegségek patogenezisében [1-3].
Jelen tanulmányunkban összefoglaljuk a miRNS-ek biogenezisét, hatásmechanizmusát, illetve aktuális ismereteink alapján áttekintjük szerepüket olyan szisztémás autoimmun betegségekben, mint a szisztémás lupus erythematosus (SLE), a primer Sjögren-szindróma (pSS), a rheumatoid arthritis (RA) és a szisztémás sclerosis $(\mathrm{SSc})$.

\section{A miRNS-ek biogenezise és funkciója}

A miRNS-biogenezis főbb lépéseit az 1. ábra szemlélteti. A miRNS-gének többsége a fehérjekódoló gének intronjaiban, intergénikus régiójában, ritkábban az exonikus régiókban fordulnak elő. A miRNS-biogenezis és -érés első lépése a sejtmagban történik, a miRNS-génekről az RNS-polimeráz II néhány százezer nukleotid hosszú, úgynevezett primer miRNS-t (pri-miRNS) ír át. A pri-miRNS-eket egy enzim-fehérje komplex ismeri fel, és továbbhasítja immár egy 70-100 nukleotid hosszú, úgynevezett prekurzor miRNS-sé (pre-miRNS). Ez a mikroprocesszorkomplex magában foglalja az endonukleolitikus hasítást végző Droshát és annak duplaszálú RNS-kötő partnerét, a DGCR8 (DiGeorge syndrome critical region gene 8)-at [4]. A pre-miRNS ezt követően a citoplazmába transzportálódik az exportin-5 szállítófehérje és guaninnukleotid-kötő fehérjék segítségével a magpóruson keresztül [5]. Az alternatív miRNS-biogenezis útja elkerüli a mikroprocesszorkomplex hasítási útvonalát, és egy másik típusú pre-miRNS, a mirtron alakul ki. Ezek közvetlenül intronokból spliceosomák által olvadnak össze. Mirtronok jelenlétét nemcsak Caenorbabditis elegansban és Drosophilában írták le, hanem emlősöknél is megfigyelték [6]. A pre-miRNS-ek további érési folyamata már a citoplazmában történik, ahol az RNáz III család egyik tagja, a Dicer enzim hasítja a premiRNS hajtúkanyartövében található kettős szálú szakaszt, ezáltal létrehozva egy 19-25 nukleotid hosszúságú miRNS/miRNS* duplexet. A miRNS* a kísérő szálat, míg a miRNS a sokkal stabilabb, érett vezető szálat jelöli. A miRNS/miRNS* duplexet helikázok választják szét, majd az érett szál beépül az Argonauta (Ago) fehérjét tartalmazó, úgynevezett RNS-indukált csendesítő komplexbe (RISC). A másik szál, a miRNS* a RISC komplex szubsztrátjaként lebomlik. A szabályozandó cél-mRNS-t a miRNS egy rövid szekvenciája, az úgynevezett „mag” régiójának 2-7 nukleotidja ismeri fel. A génszabályozás mechanizmusát a miRNS „mag” régiója és a mRNS közötti komplementaritás mértéke határozza meg. Ha a bázispárosítás tökéletes vagy közel tökéletes, a cél-mRNS endonukleotikus hasítással elbomlik, ha azonban a bázispárosítás nem teljes, a kettős szálú RNS kialakulása az adott mRNS transzlációjának gátlásához vezet. Az utóbbi folyamat következményeként a citoplazmában felhalmozódott represszált mRNS-eket P-testeknek nevezzük, melyek ismert mRNS-lebontási helyek [7]. 


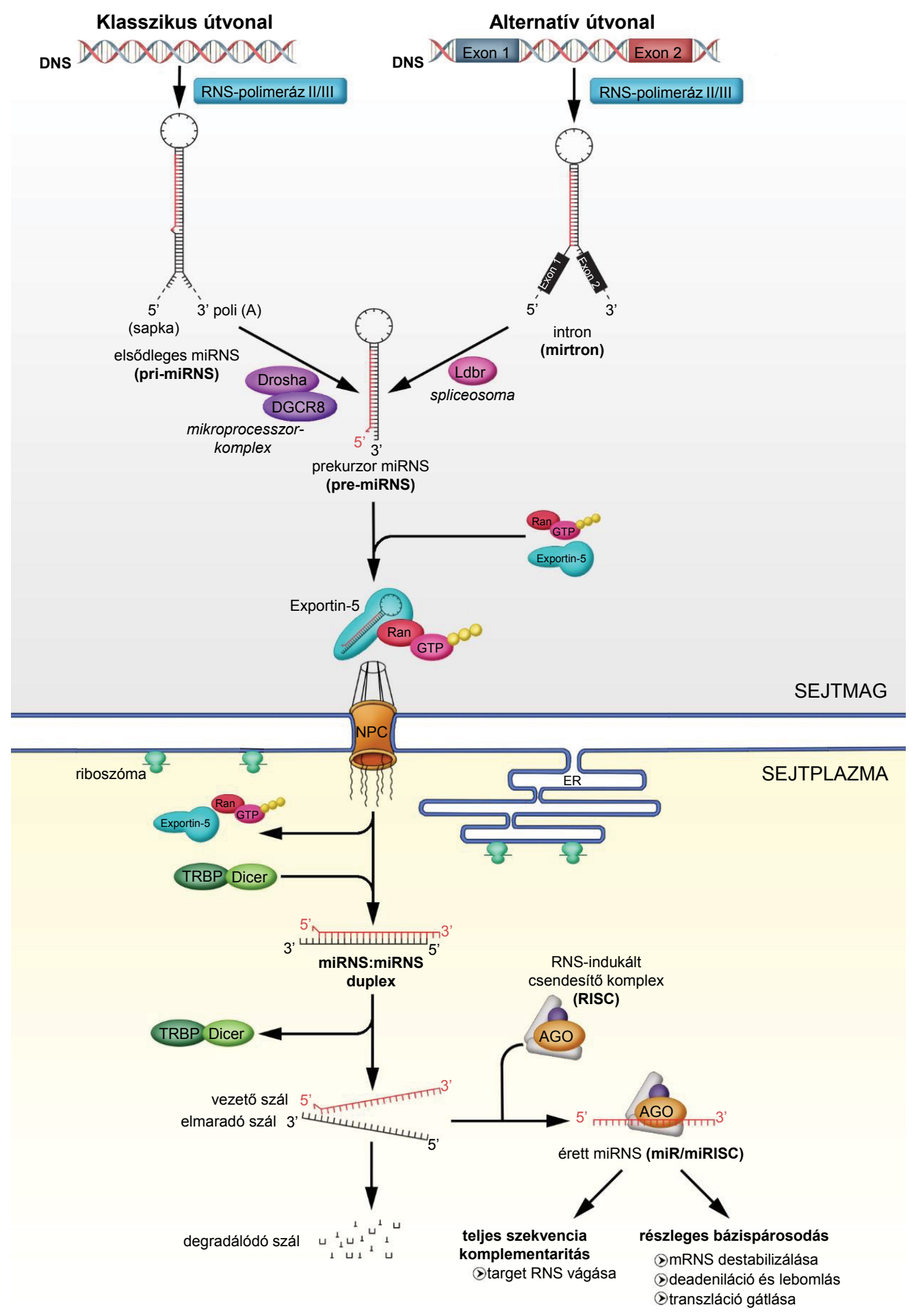

\begin{tabular}{l|l} 
1. ábra & $\begin{array}{l}\text { A miRNS-ek biogenezisének folyamata. Részletes leírás a szövegben } \\
\text { miRNS = mikro-RNS }\end{array}$
\end{tabular}

\section{A miRNS-ek szerepe az immunológiai folyamatokban}

A miRNS-ek kulcsfontosságú szabályozói az immunrendszer sejtjei érésének, proliferációjának, differenciálódásának és aktiválásának, valamint az antitestek termelésének és gyulladásos mediátorok felszabadulásának [8].
A veleszületett immunitás az első vonal a szervezet védelmében, mely a makrofágok, granulocyták, dendritikus sejtek (DC-k) és természetes ölősejtek (NK) közremúködésével fontos szerepet játszik a behatoló mikroorganizmusok elleni védekezésben. Különböző mintázatfelismerő receptorokat (PRR-eket) expresszálnak, mint például a Toll-like receptorok (TLR), melyek 
olyan immunválaszt indítanak, ami fokozza a proinflammatoricus citokinek - köztük az interferon (IFN)- $\gamma$, IFN $\beta$ vagy a tumornekrózisfaktor (TNF)- $\alpha-$ felszabadulását [9]. A különböző kórokozók konzervált struktúráinak felismerése a DC-k felszínén lévő TLR receptorokkal történik, amelyek az interleukin-1 (ILl)-kapcsolt kináz (IRAK)-1, -2, illetve -4-közvetített jelátvitel során a TNF-receptorhoz asszociált faktor (TRAF)-6 közvetítésével aktiválja a nukleárisfaktor-kappa-B $\left(\mathrm{NF}_{k} \mathrm{~B}\right)$-t , így a proinflammatoricus citokinek - mint az IL6 és a TNF - termelését. A miR-146a gén fokozott expresszióját a lipopoliszacharid jelenléte indukálja, mely a Gram-negatív baktériumok egyik sejtfalkomponense. A miR-146a képes gátolni az IRAKl és TRAF6 szignálfehérjék transzlációját, így csökkentve a $\mathrm{NF}_{\kappa} \mathrm{B}$ aktivációját [10]. A miR-147 szerepének vizsgálata során knockout egerek makrofágjaiban TLR-aktivációhoz kötött, megnövekedett gyulladásoscitokin-expressziót írtak le. A miR-146a mellett a miR-147 is negatív szabályozónak tekinthető TLR-aktivált gyulladásos válaszokban [11]. A miR-155 túlzott expressziója és a miR-125b alacsonyabb expreszsziója emelkedett TNF $\alpha$-szinttel társul. Kimutatták, hogy a miR-155 transzkripciót kódoló géneket céloz, például számos TNF $\alpha$-transzlációt elősegítő fehérjét, beleértve a Fas-kapcsolt haláldomén fehérjét (FADD), az I $\kappa B$-kináz-epszilon-t $(\mathrm{IKK} \varepsilon)$ és a TNER szupercsalád-kölcsönhatásban lévő szerin-treonin-kináz-l-et [Ripkl]), míg a miR-125b célpontja a TNF-transzkriptumok 3'UTR-je [12]. Az adaptív immunválasz T-sejtjeinek korai fejlődési stádiumában leírták, hogy a Dicer elégtelen múködése a thymusban és a perifériás lymphoid szervekben a T-sejtszám csökkenéséhez vezet [13]. Dicer-hiányos helper-T-sejtek aberráns citokintermelést mutatnak, amely emelkedett IFN $\gamma$-expresszióban nyilvánult meg [14]. A Dicer csökkent expressziója akadályozza a pro-B-sejtek pre-B-sejt irányú differenciálódását, és szignifikánsan befolyásolja az ellenanyagok diverzitását az immunglobulin $(\mathrm{Ig}) \varkappa$ variábilis régiók változatosságának növelésével. A csontvelőben a miR181, miR-150, miR-17 92 klaszter és miR-34a antigénfüggetlen módon járul hozzá a B-sejtek fejlődéséhez és differenciálódásához. A miR-155 szükséges lehet a normális B-sejt-funkcióhoz és a germináliscentrum (GC)-válaszhoz, ugyanis miR-155-hiányos egerekben kevesebb számú germinális centrumot figyeltek meg. Egérből származó B-sejtekben kimutatták a miR-34a tartós expresszióját, amely a forkhead box (Fox) pl transzkripciós faktor szuppressziójával gátolja a pro-Bsejtek pre-B-sejtekké fejlődését, így az érett B-sejtek kialakulását [15]. A miR-148 fokozott expressziója károsodott B-sejt-toleranciát okoz, és autoimmun betegségek kialakulásához vezethet. Ezenkívül gátolja az autoimmun szuppresszor GADD45 $\alpha$-t a tumorszuppresszor foszfatáz, a tenzinhomológ (PTEN)-t és a proapoptotikus Bim fehérje expresszióját, így védve az éretlen Bsejteket az apoptózistól [16].

\section{A miRNS-ek autoimmun betegségekben}

\section{Primer Sjögren-szindróma}

A pSS lassan progrediáló, szisztémás autoimmun betegség. Legfőképpen középkorú nőket érint, s elsősorban az exokrin mirigyek, mint a nyál- és könnymirigyek gyulladásához és károsodásához vezet. A betegek a külső elválasztású mirigyek diszfunkciója miatt a xerostomia és xerophthalmia jellegzetes tüneteit mutatják. Az említett úgynevezett glandularis tünetek mellett körülbelül a betegek harmadában a kórlefolyás során extraglandularis manifesztáció (EGM), mint például polyarthritis, myositis, vasculitis és polyneuropathia is kifejlődhet [17].

Egy korábbi tanulmány pSS-betegek kisnyálmirigy-biopsziáit vizsgálva a miR-126 és miR-335-5p expressziós szintjének emelkedéséről számolt be [18]. Ezzel szemben egy másik munkacsoport szerint a miR-18la és miR-16 expressziója csökkent a pSS-betegek nyálmirigyében az egészségesekéhez képest. A csökkent miRNS-szint a nyálmirigy szövettani diagnosztikájánál használt „focus score" értékekkel is összefüggést mutatott, melyek a gyulladásos folyamat súlyosságának paraméterei [19]. Alevizos és mtsai microarray-vizsgálattal pSS-betegek kisnyálmirigy-biopsziából származó mintákon leírták a mikro-RNS-ek expressziós profilját. Az alapján, hogy enyhe fokú vagy súlyos gyulladást, illetve károsodott vagy normális nyáltermelést észleltek, összehasonlították az eredményeket az egészséges kontrollokéival. Eredményeikben a hsa-miR-768-3p fokozott expressziójáról számoltak be, míg a hsa-miR-574 nemcsak alacsony expressziót mutatott a betegek biopsziáiban, hanem a focusértékekkel is negatívan korrelált [20]. A pSS-betegek jellemző szerológiai markere a Ro/SSA és La/SSB ellen irányuló autoantitestek fokozott termelődése. A betegségben számos miRNS-t azonosítottak, melyeknek feltételezetten a Ro/SSA és La/SSB antigének kódolásáért felelős mRNS-ek a célpontjai, ezek a következők: let-7b, miR-16, miR-18la, miR-200b-3p, miR-200b-5p, miR-223 és miR483-5p. A miR-16 túlzott expressziója a kisnyálmirigyekben, a miR-200b-3p emelkedett expressziója a nyálmirigyhámsejtekben, míg a miR-223 és miR-483-5p fokozott kifejeződése a PBMC-ben volt megfigyelhető pSS-betegekben a kontrollszemélyekéhez képest. Szignifikánsan alacsonyabb miR-200b-5p-szintet mutattak ki pSS-asszociált nyálkahártya-asszociált lymphoid szövet (MALT) lymphomában [21]. Korábban munkacsoportunk nemcsak megerősítette a miR-146a/b overexpresszióját a pSS-ben szenvedő betegekből nyert PBMC-ben, de szintén kimutattuk a funkcionálisan célzott gén TRAF6 túlzott kifejeződését. Ezenkívül kimutattuk az IRAKl csökkent génexpresszióját is. A TRAF6 túlzott expressziója meglepő, mivel a miR-146a gátolja a TRAF6 kifejeződését [22]. A miRNS-155 célpontjai a citokin-jelátvitelt gátló faktor-1 (SOCS1), a TGFß aktiválta kináz-1-kötő fehérje (TAB)-2 és a c-Maf mRNS-ek. Hiányában romlanak a 
B-sejtekhez kötött extrafollicularis, germináliscentrum-, illetve memóriaválaszok, valamint az IgGl-termelés is. A miR-146a túlzott expresszióját és a miR-155 csökkent kifejeződését tapasztalták pSS-ben szenvedő betegek perifériás mononukleáris sejtjeiben, melyek korrelálnak a betegség klinikai jellemzőivel. Ezek alapján fontos szerepet játszanak a betegség kialakulásában, és a jövőben potenciális markerként alkalmazhatók a kórkép diagnózisának felállításában, továbbá a betegség aktivitásának jelzésére is [23]. A betegségben megváltozott expressziót mutató miRNS-eket az 1. táblázat szemlélteti [16$19,21]$.

\section{Szisztémás lupus erythematosus}

A SLE szisztémás autoimmun betegség, melyet abnormális lymphocytaaktiváció, antinukleáris autoantitestek termelése, immunkomplexek felhalmozódása és következményes szöveti gyulladás jellemez. A betegségre jellemző klinikai kép széles spektrumot ölel fel, mivel több szervet érinthet, úgymint a bőrt, az ízületeket, a veséket, a tüdőt, az idegrendszert és a savós hártyákat is. Multifaktoriális kórkép, a klinikai manifesztációk kialakulásában számos patogén faktor, genetikai, hormonális és környezeti tényezők egyaránt szerepet játszhatnak [24].

A SLE-s betegek lymphocytáiban a miR-146a csökkent expressziójáról számoltak be, mely negatív szabályozója az I. típusú IFN-útvonalnak, az IRF5, STAT1, IRAKl és TRAF6 faktorokat gátolva. A csökkent miR-146a-expresszió tehát fontos szerepet játszhat a proinflammatoricus szignalizációs útvonalak aktiválódásában [25]. A miR-150 szintje emelkedett az érett, nyugvó B-sejtekben, és a c-Myb transzkripciós faktor szabályozása által regulálja a B-sejtek fejlődését és migrációját [26]. A miR-326-nak a SLE patogenezisében be- töltött szerepe még tisztázatlan, bár emelkedett szintjét írták le experimentális lupusmodellekben, például MRL/ lpr egerekben. Fokozott expressziója hozzájárul a plasmoblastok fejlődéséhez és az erythroblastosisvírus E26 onkogén homológ-1 (Ets-1) downregulációján keresztül csökkenti az antitestek termelését [27]. A T- és Bsejtekben a miR-126, miR-21, miR-146a, miR-155, miR-1246 megváltozott szintjei B-sejt-hiperaktivitáshoz és autoantitest-termeléshez vezethetnek [28]. Lupus nephritises (LN) betegeknél leírták, hogy a miR-410 fokozott expressziója szignifikánsan csökkenti a profibroticus faktorok szintjét, mint például a transzformáló növekedési faktor- $\beta 1$ (TGFß1)-et, gátolva az IL6 szekrécióját [29]. A miR-148a-3p expressziós szintje szignifikánsan magasabb az aktív LN-nel társult SLE-s betegek perifériás vérében és glomerularis sejtjeiben. A miR-148a-3p fokozott expressziója felgyorsítja a glomerularis sejtek proliferációját, és fokozza a proliferáló sejtmagantigén (PCNA) expresszióját, következésképpen csökkentve a phosphatase and tensin homolog deleted on chromosome-10 (PTEN) expressziós szintjét [30]. A miR130b-3p szignifikáns overexpresszióját mutatták ki korai állapotú veseérintettséget mutató SLE-s betegek szérumában, összehasonlítva az egészséges kontrollok értékeivel. Egy nemrég publikált vizsgálat szerint a szérummiR-130b-3p nincs hatással a SLE-betegség aktivitására, de összefüggést mutat a vesekárosodással, mivel a szérum emelkedett miR-130b-3p-expressziója pozitívan korrelál a 24 órás proteinuria mértékével és a vese krónikus gyulladásának fokával [31]. Másrészről a miR-29c expressziója a vizeletexosomákban erôs negatív korrelációt mutatott a betegség stádiumával, de az aktuális vesefunkcióval (eGFR és kreatininszint) nem, így a vizelet exosomáinak vizsgálata új, ideális forrást jelenthet a LN stádiumának meghatározására és nyomon követésére [32]. Ezenfelül számos miRNS expressziója mutat emel-

1. táblázat | Megváltozott expressziós szintet mutató miRNS-ek primer Sjögren-szindrómában

\begin{tabular}{|c|c|c|c|c|c|}
\hline \multirow[t]{2}{*}{ Betegség } & \multirow[t]{2}{*}{ Minta } & \multicolumn{2}{|c|}{ A miRNS-expresszió } & \multirow[t]{2}{*}{ A miRNS jelentősége } & \multirow[t]{2}{*}{ Hivatkozás } \\
\hline & & emelkedett & csökkent & & \\
\hline \multirow{11}{*}{$\begin{array}{l}\text { Primer } \\
\text { Sjögren- } \\
\text { szindróma }\end{array}$} & \multirow{7}{*}{ Nyálmirigy } & miR-126 & & Nyál-cisztatin-S révén közvetlen immunmoduláló hatás, veleszü- & {$[16]$} \\
\hline & & $\operatorname{miR}-335-5 p$ & & letett oralis immunitas & \\
\hline & & & miR-18la & Ro/SSA, La/SSB szabályozása & [17] \\
\hline & & & $\operatorname{miR}-16$ & & \\
\hline & & hsa-miR-768-3p & hsa-miR-574 & Gyulladásos infiltrátumokban kimutatható & {$[18]$} \\
\hline & & miR-16 & & Ro/SSA, La/SSB szabályozása & [19] \\
\hline & & miR-200-3p & & & \\
\hline & \multirow{4}{*}{ PBMC } & $\operatorname{miR}-223$ & & Ro/SSA, La/SSB szabályozása & [19] \\
\hline & & $\operatorname{miR}-483-5 p$ & & & \\
\hline & & $\operatorname{miR}-146 a / b$ & & TLR-szignál és NFkB negatív feedback szabályozása & {$[21]$} \\
\hline & & & miR-155 & Proinflammatoricus citokin termelésének szabályozása & \\
\hline
\end{tabular}

miRNS = mikro-RNS; NFאB = nukleárisfaktor-kappa-B; PBMC = perifériás vér mononukleáris sejt; SSA = Sjögren-szindrómával összefüggó A-antigén; SSB = Sjögren-szindrómával összefüggő B-antigén; TLR = Toll-szerű receptor 
kedést a vizeletexosoma-frakcióban, összehasonlítva a sejtmentes és exosoma nélküli felülúszó frakcióval, különösen LN-ben. Az exosomalis miRNS-ek közül a miR146a fejeződött ki a leginkább SLE-ben szenvedő betegeknél aktív LN-nel, szemben a kontrollcsoporttal vagy a LN nélküli SLE-s betegekkel [33]. PBMC-ben microarray-analízis alapján a miR-189, miR-61, miR-78, miR21， miR-142-3p， miR-342， miR-299-3p， miR-198, miR-298 szintje emelkedést mutatott, míg a miR-196a, miR-17-5p, miR-409-3p, miR-141, miR-383, miR-112, miR-184 esetében csökkenést tapasztaltak [34]. A miR873 fokozott expressziót mutat SLE-s betegekben, és pozitívan korrelál a betegség aktivitásával. A Foxol-et célozza, mely ismert, mint a Thl7-sejt-differenciáció gátlója, így e miRNS gátlása új terápiás célpont lehet a jövőben [35]. Szisztémás lupus erythematosusban a megváltozott expressziós szintet mutató miRNS-eket a 2. táblázatban foglaltuk össze [23, 24, 28-30, 32, 33].

\section{Szisztémás sclerosis}

A szisztémás sclerosist ( $\mathrm{SSc}$-t) a bőr és a belső szervek, mint például a szív, a tüdő és a vesék fokozott fibrosisa és szöveti károsodása jellemzi. A SSc két típusát különböztethetjük meg a bőr érintettségének mértéke alapján: a limitált és a diffúz cutan formát. Az elmúlt évtized kutatásai egyre több információt szolgáltatnak a miRNS-ek szerepéról a fibrogenezis szabályozásában. A vizsgálatok alapján SSc-ban a fibroblastok kollagéntermelését kórosan fokozzák a következő miRNS-ek: miR-335, miR-150,
miR-132, miR-27b, miR-27a, miR-16, miR-15b. A miR-150 az egyik legfontosabb miRNS a betegség patogenezisében, mely a c-Myb által a B-sejtek érési folyamatát szabályozza. További vizsgálatok a miR-150 fokozott expresszióját írták le az érett T-sejtek további differenciálódása során, azonban a miR-150 expressziós szintje már csökkenő tendenciát mutat a Th1-és a Th2-sejtek kialakulása során [36]. A miR-483-5p expressziója emelkedett a szérumban, a fibroblastokban és az endothelsejtekben, továbbá korrelál a Rodnan-féle bőrpontszámmal (Rodnan skin score) SSc-s betegekben. Funkcióját tekintve a fibrosis folyamatához kapcsolódó gének expresszióját modulálja, endothelsejtekben emeli az $\alpha$-simaizom aktin ( $\alpha$ SMA) és a simaizom aktin-22 (SMA22) transzkripciós faktorok szintjét, melyek ismert myofibroblastdifferenciációs markerek [37]. A tüdőfibrosisban a miR-155-nek van meghatározó szerepe, expresszióját az IL1 $\beta$ és az inflammasomák aktiválása indukálja. MiR-155 hiányában nem indul el a fibroblastokban az inflammasomamediált kollagénszintézis [38]. Egy másik, széles körben tanulmányozott miRNS, a miR-29a az extracellulárismátrix (ECM)-szintézis legfontosabb közvetlen szabályozójának tekinthető. A TABl-gént regulálja, és a dermalis fibroblastok apoptózisához vezethet, ami alacsonyabb szöveti metalloproteinázgátló (TIMPl)-termelést okozva a mátrix metalloproteináz (MMPl) szintjének növelésével elősegíti a kollagén degradációját. Mindezek alapján a miR-29a potenciális terápiás célpont lehet a SSc kezelésében [39]. A SSc-ban szenvedő betegek dermalis fibroblastjaiban a miR-29a

2. táblázat | Szisztémás lupus erythematosusban megváltozott expressziót mutató miRNS-ek

\begin{tabular}{|c|c|c|c|c|c|}
\hline \multirow[t]{2}{*}{ Betegség } & \multirow[t]{2}{*}{ Minta } & \multicolumn{2}{|c|}{ A miRNS-expresszió } & \multirow[t]{2}{*}{ A miRNS jelentősége } & \multirow[t]{2}{*}{ Hivatkozás } \\
\hline & & emelkedett & csökkent & & \\
\hline \multirow{15}{*}{$\begin{array}{l}\text { Szisztémás lupus } \\
\text { erythematosus }\end{array}$} & \multirow{11}{*}{ PBMC } & & miR-146a & $\begin{array}{l}\text { Gyulladásos válaszok negatív szabályozása, I-es típusú } \\
\text { IFN-termelés gátlása }\end{array}$ & {$[23]$} \\
\hline & & $\operatorname{miR}-189$ & miR-196a & & \\
\hline & & miR-61 & miR-17-5p & & \\
\hline & & $\operatorname{miR}-78$ & $\operatorname{miR}-409-3 p$ & & \\
\hline & & miR-21 & miR-141 & & \\
\hline & & miR-142-3p & miR-383 & Nem ismert & {$[32]$} \\
\hline & & $\operatorname{miR}-342$ & miR-112 & & \\
\hline & & miR-299-3p & miR-184 & & \\
\hline & & $\operatorname{miR}-198$ & & & \\
\hline & & $\operatorname{miR}-298$ & & & \\
\hline & & $\operatorname{miR}-873$ & & Th17-differenciáció szabályozása & {$[33]$} \\
\hline & Érett, nyugvó B-sejt & $\operatorname{miR}-150$ & & B-sejtek érésének, migrációjának szabályozása & [24] \\
\hline & Glomerularis sejt & miR-148a-3p & & Glomerularis sejtek proliferációjának szabályozása & [28] \\
\hline & Szérum & miR-130b-3p & & Proteinuriával függ össze & [29] \\
\hline & Vizeletexosoma & $\operatorname{miR}-29 c$ & & Korrelál vesefibrosissal & {$[30]$} \\
\hline
\end{tabular}

IFN = interferon; miRNS = mikro-RNS; PBMC = perifériás vér mononukleáris sejt 
szintjének emelkedése csökkenti a TNF $\alpha$-termelést. Ezenkívül a Bcl-2-expresszió fokozódik SSc-fibroblastokban, és a Bax : Bcl-2 arány szignifikánsan alacsonyabb a kontrollokhoz képest. A miR-29a azonban megváltoztatja a Bcl-2 családba tartozó fehérjék (Bax, Bcl-2 és BclXL) expressziós profilját, továbbá a miR-29a egy antifibroticus faktor, ugyanis apoptózist indukál, és csökkenti az extracelluláris mátrix (ECM) termelését SSc-fibroblastokban [40]. Iwamoto és mtsai a miR-193b csökkent szintjéról számoltak be SSc-fibroblastokban és az érintett bőrszakaszokban. A miR-193b downregulálása indukálja az urokináz típusú plazminogénaktivátor (uPA) enzim és mRNS expresszióját, amely fokozza SSc-s bőrben a vascularis simaizomsejtek számát [41]. A betegségben megváltozott expressziót mutató miRNS-eket a 3. táblázatban foglaltuk össze [35-39].

\section{Rheumatoid arthritis}

A RA az egyik leggyakoribb autoimmun betegség, prevalenciája a felnőttek körében világszerte 0,3-1\% körül mozog. A betegségben az ízületi synovium az elsődleges érintett terület, ahol a krónikus gyulladásos folyamatok következtében az ízületet alkotó képletek irreverzibilis pusztulása játszódik le $[42,43]$. Egy nemrég publikált tanulmány aktív RA-ban és osteoarthritisben (OA) szenvedő betegek makrofág sejtjeiben vizsgálta a miRNS-ek expresszióját. Eredményeik alapján a következő 7 miRNS mutatott alacsony expressziós szintet az OA-betegekhez képest: miR-99a, miR-100, miR-125b, miR199-3p, miR-199-5p, miR-152 és miR-214. Ezzel szemben a miR-223 kifejeződése fokozódott a RA-betegek makrofágjaiban. Vizsgálataikkal azt is sikerült igazolni, hogy myeloid sejtekben a miR-223 magas szintje az arilhidrokarbon-receptor (AHR) nukleáris transzlokátor (ARNT) fehérje szintjének csökkentésével funkcionálisan rontja az AHR/ARNT útvonalat. Az AHR-aktiváció kapcsolódhat a RA patogeneziséhez, mivel makrofágokban az AHR-agonisták gátolják a proinflammatoricus citokinek expresszióját [44]. Ma már egyértelmü, hogy az IL17 gyulladásos citokin hozzájárul a RA krónikusságának kialakulásához. Egy nemrég publikált tanulmányban figyelték meg, hogy ízületi porcsejtekben a miR-23a gátolja az IL17 indukálta NFkB-aktivációt és bizonyos proinflammatoricus mediátorok, mint például az IL6, MCP1, MMP3 expresszióját. A miR-23a expressziója fordítottan arányos az I $\ltimes B$-kináz-komplex- $\alpha(\mathrm{IKK} \alpha)$ expressziójával az ízületi porcsejtekben [45]. Egy másik munkacsoport Th17-es sejtekkel végzett vizsgálata arra világított rá, hogy a ROR $\gamma$ t és STAT3 transzkripciós faktorok szintje szignifikánsan növekszik a RA-betegek PBMC-sejtjeiben, miközben a miR-30la-3p is túlzott mértékben expresszált [46]. Mások a regulatív T-sejtek (Treg)/Th17 egyensúly vizsgálatára koncentráltak a Maresin-1 (MaRl), egy lipidmediátor függvényében, és megfigyelték, hogy a kezelés serkenti a miR-2l expreszszióját. Köztudott, hogy a Treg-sejtek transzkripciós faktorának, a FoxP3-nak a szintje alacsonyabb aktív RAban, míg a Th17 transzkripciós faktorának, a RORc-nek a szintje viszont emelkedett. Eredményeik alapján a miR-21 fokozott kifejeződése emeli a Treg-sejt-arányt, helyreállítja a MaRl indukálta Treg/Thl7 egyensúlyt, ezáltal mérsékelve a RA progresszióját [47]. Korábban már kimutatták a kapcsolatot a miRNS-ek expressziós profiljainak változásai és a betegség patomechanizmusa között. Kanadai populációban igazolták a miR-146a és a miR-155 emelkedett expresszióját mind a teljes vérmintákban, mind a RA-betegek PBMC-sejtjeiben [48]. A miR-573 negatív szabályozó lehet RA-ban, mivel a miR573 képes gátolni a mitogénaktivált proteinkináz (MAPK) aktiválódását, melyre mint a RA-kezelés egyik lehetséges célpontjaként tekintünk [49]. Egy másik terápiás célpont lehet a miR-29a, mely erősen csökkent expressziót mutat szérumban, a synovialis szövetben és a synovialis fibroblastokban (FLS). A miRNS-29a fokozott kifejeződése szignifikánsan csökkenti a sejtek proliferációját, elősegíti az apoptózist, és gátolja a gyulladásos citokinek kifejeződését a STAT3 transzkripciós faktoron keresztül, továbbá csökkenti a ciklin Dl és Bcl2 fehérjék szintjét is [50]. A miR-192 is lehetséges terápiás célpont, mivel szerepet játszik a FLS proliferációjának gátlásában. A miR-192 fokozott expressziója apoptózist indukál a kaszpáz-3 aktivitásának fokozásával és a $\mathrm{Bax} / \mathrm{Bcl} 2$ arány növelésével. Célpont lehet még a caveolin-1 is, mely gátolja a sejtproliferációt, és elősegíti az apoptotikus folyamatokat [51]. A miR-140-5p pedig a TLR4 expresszió-

3. táblázat | Megváltozott expressziós szintet mutató miRNS-ek szisztémás sclerosisban

\begin{tabular}{|c|c|c|c|c|c|}
\hline \multirow[t]{2}{*}{ Betegség } & \multirow[t]{2}{*}{ Minta } & \multicolumn{2}{|c|}{ A miRNS-expresszió } & \multirow[t]{2}{*}{ A miRNS jelentősége } & \multirow[t]{2}{*}{ Hivatkozás } \\
\hline & & emelkedett & csökkent & & \\
\hline \multirow{4}{*}{$\begin{array}{l}\text { Szisztémás } \\
\text { sclerosis }\end{array}$} & $\begin{array}{l}\text { Szérumfibroblast } \\
\text { Endothelsejt }\end{array}$ & \multicolumn{2}{|l|}{ miR-483-5p } & Myofibroblastdifferenciáció & {$[35]$} \\
\hline & Tüdőfibrosis & miR-155 & & Inflammasomamediált kollagénszintézis szabályozása & {$[36]$} \\
\hline & \multirow{2}{*}{ Fibroblast } & $\operatorname{miR}-29 a$ & & ECM-termelés szabályozása & {$[37,38]$} \\
\hline & & & miR-193b & Vascularis simaiziomsejtek számának szabályozása & {$[39]$} \\
\hline
\end{tabular}

$\mathrm{ECM}=$ extracelluláris mátrix; miRNS = mikro-RNS 
4. táblázat $\mid$ Rheumatoid arthritisben megváltozott expressziót mutató miRNS-ek

\begin{tabular}{|c|c|c|c|c|c|}
\hline \multirow[t]{2}{*}{ Betegség } & \multirow[t]{2}{*}{ Minta } & \multicolumn{2}{|c|}{ A miRNS-expresszió } & \multirow[t]{2}{*}{ A miRNS jelentősége } & \multirow[t]{2}{*}{ Hivatkozás } \\
\hline & & emelkedett & csökkent & & \\
\hline \multirow{17}{*}{$\begin{array}{l}\text { Rheumatoid } \\
\text { arthritis }\end{array}$} & \multirow{8}{*}{ Makrofág } & miR-223 & & AHR/ARNT útvonal szabályozása & \multirow{8}{*}[41]{} \\
\hline & & & miR-99a & \multirow{7}{*}{ Nem ismert } & \\
\hline & & & miR-100 & & \\
\hline & & & $\operatorname{miR}-125 b$ & & \\
\hline & & & miR-199-3p & & \\
\hline & & & miR-199-5p & & \\
\hline & & & miR-152 & & \\
\hline & & & miR-214 & & \\
\hline & Ízületi porcsejt & $\operatorname{miR}-23 a$ & & $\begin{array}{l}\text { IL17-mediált proinflammatoricus mediátorok } \\
\text { expressziójának gátlása }\end{array}$ & {$[42]$} \\
\hline & Naiv CD4+ & & miR-21 & Treg/Th17 egyensúly szabályozása & {$[44]$} \\
\hline & PBMC & miR-30la-3p & & Th17-sejt-differenciáció szabályozása & {$[43]$} \\
\hline & Teljes vér & miR-146a & & & \\
\hline & & miR-155 & & mmmuntorerancia szaoaryozasa & {$[40]$} \\
\hline & $\begin{array}{l}\text { Szérum- } \\
\text { synovialisszövet } \\
\text { Synovialis fibroblast }\end{array}$ & & $\operatorname{miR}-29 a$ & $\begin{array}{l}\text { FLS-sejtek proliferációjának és gyulladási citokinek } \\
\text { termelésének gátlása }\end{array}$ & [47] \\
\hline & Synovialis fibroblast & & miR-573 & Gyulladás és FLS-migráció szabályozása & {$[46]$} \\
\hline & & & miR-192 & FLS-apoptózis szabályozása & {$[48]$} \\
\hline & & & miR-140-5p & FLS-sejtek proliferációjának szabályozása & [49] \\
\hline
\end{tabular}

$\mathrm{AHR}=$ arilhidrokarbon-receptor; ARNT = AHR nukleáris transzlokátor; FLS = synovialis fibroblast; miRNS = mikro-RNS; PBMC = perifériás vér mononukleáris sejt

jának szabályozásán keresztül akadályozza a synovialis fibroblastok proliferációját és az IL6 és IL8 gyulladásos citokinek szintjét [52]. Rheumatoid arthritisben a megváltozott expressziós szintet mutató miRNS-eket a 4 . táblázat szemlélteti [41-49].

\section{Következtetések}

Az elmúlt években fokozott figyelem irányult a miRNSek autoimmun betegségekben betöltött szerepére. Egyre több vizsgálat támasztja alá, hogy egyes miRNS-ek expressziós szintjének változása a keringésben, a különböző immunkompetens sejtekben, illetve szövetekben fontos szerepet játszhat az autoreaktív immunfolyamatok kialakulásában és az autoimmun betegségek patogenezisében. Fontos azonban kiemelni, hogy egyes miRNSek egy időben akár több száz mRNS-transzkriptumot is szabályoznak, és egy adott mRNS-t is számos miRNS regulálhat, melyek így rendkívül összetett szabályozási rendszert alkotnak. Így mind a mRNS, mind a miRNS expressziós szintjének teljes körü vizsgálata szükséges a miRNS célgénjeinek precíz azonosításához, ezáltal kaphatunk pontosabb betekintést a mRNS és a miRNS közötti funkcionális összefüggésekbe is. Funkcionális kísérletes vizsgálatok szükségesek az abnormálisan expresszált miRNS-ek és a betegség kialakulása közötti összefüggés igazolására és megállapítására. Ezenkívül a miRNS-ek rendellenes expressziójának alapjául szolgáló folyamatokat és az ezeket szabályozó egyéb tényezők hatását is vizsgálni kell. A mechanizmusok megértésével azonosíthatóvá válnak olyan miRNS-ek, illetve mRNS-ek, melyek biomarkerei lehetnek az egyes betegségeknek, segíthetnek a diagnózisban és a prognózis megállapításában, illetve potenciális terápiás célpontokként alkalmazhatók az autoimmun betegségek modern terápiájában.

Anyagi támogatás: A kézirat megírása az Emberi Erőforrások Minisztériuma ÚNKP-17-4-es kódszámú Új Nemzeti Kiválóság Programja, illetve a NKFIH (OTKA) K124177 és OTKA PD121327-es projektek támogatásával történt.

Szerzői munkamegosztás: J. I., Sz. K.: A kézirat megírása, a táblázatok és az ábra elkészítése. Z. M.: A kézirat korrekciója. P. G.: A kézirat koncepciójának kialakítása, a kézirat kiegészítése és véglegesítése. Az első két szerző, J. I. és Sz. K. azonos mértékben járult hozzá a kézirat elkészüléséhez. A cikk végleges változatát valamennyi szerző elolvasta és jóváhagyta.

Érdekeltségek: A szerzőknek nincsenek érdekeltségeik. 


\section{Irodalom}

[1] Chen JQ, Papp G, Szodoray P, et al. The role of microRNAs in the pathogenesis of autoimmune diseases. Autoimmun Rev. 2016; 15: 1171-1180.

[2] Nagy Z, Decmann Á, Perge P, et al. Pathogenic and diagnostic roles of microRNAs in adrenocortical tumours. [A mikro-RNS ek patogenetikai és diagnosztikai szerepe mellékvesekéreg-carcinomában.] Orv Hetil. 2018; 159: 245-251. [Hungarian]

[3] Decmann Á, Perge P, Nagy Z, et al. Circulating microRNAs in the diagnostics of endocrine neoplasms. [Keringő mikroRNS-ek az endokrin daganatok diagnosztikájában.] Orv. Hetil. 2017; 158: 483-490. [Hungarian]

[4] Graves P, Zeng Y. Biogenesis of mammalian microRNAs: a global view. Genomics Proteomics Bioinformatics 2012; 10: 239245 .

[5] Yi R, Qin Y, Macara IG, et al. Exportin-5 mediates the nuclear export of pre-microRNAs and short hairpin RNAs. Genes Dev. 2003; 17: 3011-3016.

[6] Westholm JO, Lai EC. Mirtrons: microRNA biogenesis via splicing. Biochimie 2011; 93: 1897-1904.

[7] Carthew RW, Sontheimer EJ. Origins and mechanisms of miRNAs and siRNAs. Cell 2009; 136: 642-655.

[8] Baulina NM, Kulakova OG, Favorova OO. MicroRNAs: the role in autoimmune inflammation. Acta Naturae 2016; 8: 21-33.

[9] Chen JQ, Szodoray P, Zeher M. Toll-like receptor pathways in autoimmune diseases. Clin Rev Allergy Immunol. 2016; 50: $1-17$

[10] Hou J, Wang P, Lin L, et al. MicroRNA-146a feedback inhibits RIG-I-dependent type I IFN production in macrophages by targeting TRAF6, IRAK1, and IRAK2. J Immunol. 2009; 183 $2150-2158$

[11] Liu G, Friggeri A, Yang Y, et al. miR-147, a microRNA that is induced upon Toll-like receptor stimulation, regulates murine macrophage inflammatory responses. Proc Natl Acad Sci USA 2009; 106: 15819-15824.

[12] Tili E, Michaille JJ, Cimino A, et al. Modulation of miR-155 and miR-125b levels following lipopolysaccharide/TNF-alpha stimulation and their possible roles in regulating the response to endotoxin shock. J Immunol. 2007; 179: 5082-5089.

[13] Cobb BS, Nesterova TB, Thompson E, et al. T cell lineage choice and differentiation in the absence of the RNase III enzyme Dicer. J Exp Med. 2005; 201: 1367-1373.

[14] Muljo SA, Ansel KM, Kanellopoulou C, et al. Aberrant T cell differentiation in the absence of Dicer. J Exp Med. 2005; 202: 261-269.

[15] Li J, Wan Y, Ji Q, et al. The role of microRNAs in B-cell development and function. Cell Mol Immunol. 2013; 10: 107-112.

[16] Gonzalez-Martin A, Adams BD, Lai M, et al. The microRNA miR-148a functions as a critical regulator of B cell tolerance and autoimmunity. Nat Immunol. 2016; 17: 433-440.

[17] Szántó A, Szodoray P, Kiss E, et al. Clinical, serologic, and genetic profiles of patients with associated Sjögren's syndrome and systemic lupus erythematosus. Hum Immunol. 2006; 67: $924-$ 930.

[18] Martini D, Gallo A, Vella S, et al. Cystatin S - a candidate biomarker for severity of submandibular gland involvement in Sjögren's syndrome. Rheumatology 2017; 56: 1031-1038.

[19] Wang Y, Zhang G, Zhang L, et al. Decreased microRNA-181a and -16 expression levels in the labial salivary glands of Sjögren syndrome patients. Exp Ther Med. 2018; 15: 426-432.

[20] Alevizos I, Alexander S, Turner RJ, et al. MicroRNA expression profiles as biomarkers of minor salivary gland inflammation and dysfunction in Sjögren's syndrome. Arthritis Rheum. 2011; 63: 535-544.

[21] Gourzi VC, Kapsogeorgou EK, Kyriakidis NC, et al. Study of microRNAs (miRNAs) that are predicted to target the autoanti- gens Ro/SSA and La/SSB in primary Sjögren's syndrome. Clin Exp Immunol. 2015; 182: 14-22.

[22] Zilahi E, Tarr T, Papp G, et al. Increased microRNA-146a/b, TRAF6 gene and decreased IRAKl gene expressions in the peripheral mononuclear cells of patients with Sjögren's syndrome. Immunol Lett. 2012; 141: 165-168.

[23] Shi H, Zheng LY, Zhang P, et al. miR-146a and miR-155 expression in PBMCs from patients with Sjögren's syndrome. J Oral Pathol Med. 2014; 43: 792-797.

[24] Honarpisheh M, Köhler P, von Rauchhaupt E, et al. The involvement of microRNAs in modulation of innate and adaptive immunity in systemic lupus erythematosus and lupus nephritis. J Immunol Res. 2018; 2018: 4126106.

[25] Lai NS, Koo M, Yu CL, et al. Immunopathogenesis of systemic lupus erythematosus and rheumatoid arthritis: the role of aberrant expression of non-coding RNAs in T cells. Clin Exp Immunol. 2016; 187: 327-336.

[26] Meinzinger J, Jäck HM, Pracht K. miRNA meets plasma cells "How tiny RNAs control antibody responses". Clin Immunol. 2018; 186: 3-8.

[27] Xia Y, Tao JH, Fang X, et al. MicroRNA-326 upregulates B cell activity and autoantibody production in lupus disease of MRL/ Ipr mice. Mol Ther Nucleic Acids 2018; 11: 284-291.

[28] Husakova M. MicroRNAs in the key events of systemic lupus erythematosus pathogenesis. Biomed Pap Med Fac Univ Palacky Olomouc Czech Repub. 2016; 160: 327-342.

[29] Liu D, Zhang N, Zhang J, et al. miR-410 suppresses the expression of interleukin- 6 as well as renal fibrosis in the pathogenesis of lupus nephritis. Clin Exp Pharmacol Physiol. 2016; 43: 616625.

[30] Qingjuan L, Xiaojuan F, Wei Z, et al. miR-148a-3p overexpression contributes to glomerular cell proliferation by targeting PTEN in lupus nephritis. Am J Physiol Cell Physiol. 2016; 310: C470-C478.

[31] Wang W, Mou S, Wang L, et al. Up-regulation of serum MiR-130b-3p level is associated with renal damage in early lupus nephritis. Sci Rep. 2015; 5: 12644.

[32] Solé C, Cortés-Hernández J, Felip ML, et al. miR-29c in urinary exosomes as predictor of early renal fibrosis in lupus nephritis. Nephrol Dial Transplant. 2015; 30: 1488-1496.

[33] Perez-Hernandez, J, Forner MJ, Pinto C, et al. Increased urinary exosomal microRNAs in patients with systemic lupus erythematosus. PLoS ONE 2015; 10: e0138618.

[34] Xiao G, Zuo X: Epigenetics in systemic lupus erythematosus. Biomed Rep. 2016; 4: 135-139.

[35] Liu L, Liu Y, Yuan M, et al. Elevated expression of microRNA873 facilitates Thl7 differentiation by targeting forkhead box Ol (Foxol) in the pathogenesis of systemic lupus erythematosus. Biochem Biophys Res Commun. 2017; 492: 453-460.

[36] Aslani S, Sobhani S, Gharibdoost F, et al. Epigenetics and pathogenesis of systemic sclerosis; the ins and outs. Human Immunol. 2018; 79: 178-187.

[37] Chouri E, Servaas NH, Bekker CP. Serum microRNA screening and functional studies reveal miR-483-5p as a potential driver of fibrosis in systemic sclerosis. J Autoimmun. 2018; 89: 162-170.

[38] Artlett CM, Sassi-Gaha S, Hope JL, et al. Mir-155 is overexpressed in systemic sclerosis fibroblasts and is required for NLRP3 inflammasome-mediated collagen synthesis during fibrosis. Arthritis Res Ther. 2017; 19: 144.

[39] Ciechomska M, O'Reilly S, Suwara M, et al. MiR-29a reduces TIMP-1 production by dermal fibroblasts via targeting TGF- $\beta$ activated kinase 1 binding protein 1 , implications for systemic sclerosis. PLoS ONE 2014; 9: el15596.

[40] Jafarinejad-Farsangi S, Farazmand A, Mahmoudi M, et al. MicroRNA-29a induces apoptosis via increasing the $\mathrm{Bax}$ : $\mathrm{Bcl}-2$ ratio in dermal fibroblasts of patients with systemic sclerosis. Autoimmunity $2015 ; 48$ : 369-378. 
[41] Iwamoto N, Vettori S, Maurer B, et al. Downregulation of miR$193 \mathrm{~b}$ in systemic sclerosis regulates the proliferative vasculopathy by urokinase-type plasminogen activator expression. Ann Rheum Dis. 2016; 75: 303-310.

[42] Moran-Moguel MC, Petarra-del Rio S, Mayorquin-Galvan EE, et al. Rheumatoid arthritis and miRNAs: a critical review through a functional view. J Immunol Res. 2018; 2018: 2474529.

[43] Pál I, Pusztai A, Csomor P, et al. Experience with a rheumatoid arthritis biobank: analysis of biological samples and clinical data of 204 patients. [Rheumatoid arthritises biobankkal szerzett tapasztalataink: 204 beteg biológiai mintáinak és klinikai adatainak összevetése.] Orv Hetil. 2017; 158: 270-277. [Hungarian]

[44] Ogando J, Tardáguila M, Díaz-Alderete A, et al. Notch-regulated miR-223 targets the aryl hydrocarbon receptor pathway and increases cytokine production in macrophages from rheumatoid arthritis patients. Sci Rep. 2016; 6: 20223.

[45] Hu J, Zhai C, Hu J, et al. MiR-23a inhibited IL-17-mediated proinflammatory mediators expression via targeting $\mathrm{IKK} \alpha$ in articular chondrocytes. Int Immunopharmacol. 2017; 43: 1-6.

[46] Tang X, Yin K, Zhu H, et al. Correlation between the expression of microRNA-30la-3p and the proportion of Th17 cells in patients with rheumatoid arthritis. Inflammation 2016; 39: 759767

[47] Jin S, Chen H, Li Y, et al. Maresin 1 improves the Treg/Th17 imbalance in rheumatoid arthritis through miR-21. Ann Rheum Dis. 2018; 77: 1644-1652.
[48] Mookherjee N, El-Gabalawy HS. High degree of correlation be tween whole blood and PBMC expression levels of miR-155 and miR-146a in healthy controls and rheumatoid arthritis patients. J Immunol Methods 2013; 400-401: 106-110.

[49] Wang L, Song G, Zheng Y, et al. miR-573 is a negative regulator in the pathogenesis of rheumatoid arthritis. Cell Mol Immunol. 2016; 13: 839-849.

[50] Liu J, Fei D, Xing J, et al. MicroRNA-29a inhibits proliferation and induces apoptosis in rheumatoid arthritis fibroblast-like synoviocytes by repressing STAT3. Biomed Pharmacother. 2017; 96: 173-181

[51] Li S, Jin Z, Lu X. MicroRNA-192 suppresses cell proliferation and induces apoptosis in human rheumatoid arthritis fibroblastlike synoviocytes by downregulating caveolin 1. Mol Cell Biochem. 2017; 432: 123-130.

[52] Li H, Guan SB, Lu Y, et al. MiR-140-5p inhibits synovial fibroblasts proliferation and inflammatory cytokines secretion through targeting TLR4. Biomed Pharmacother. 2017; 96: 208-214.

\title{
MEGHÍVó
}

\section{A Szent János Kórház és Észak-budai Egyesített Kórházak Tudományos Bizottsága tisztelettel meghívja az érdeklődőket a következő tudományos ülésére.}

\author{
Időpont: 2019. április 25. (csütörtök) 14 óra
}

Helyszín: Szent János Kórház Auditóriuma - 1125 Budapest, Diós árok 1-3.

Téma: A szem öregedése

Üléselnök: Prof. Dr. Jánosi András

\section{Program:}

Dr. Gombos Katalin: A szemfenéki meszesedések (macula degeneratio) 10 perc

Dr. Burka Gabriella: A szem időskori keringési zavarai

10 perc

Dr. Reichard Lilla: A lencse elváltozásai, ezek speciális szempontjai igen idős betegeknél

10 perc

Dr. Hertelendy Anna: Az idegrendszer és a szem idős korban

10 perc

Dr. Erdei Zsuzsa, Dr. Gombos Katalin: Összefoglaló: mit tehetünk a fentiek megelőzésére

10 perc

\section{Minden érdeklődőt szeretettel várunk.}

A cikk a Creative Commons Attribution 4.0 International License (https://creativecommons.org/licenses/by/4.0/) feltételei szerint publikált Open Access közlemény, melynek szellemében a cikk bármilyen médiumban szabadon felhasználható, megosztható és újraközölhetö, feltéve, hogy az eredeti szerző és a közlés helye, illetve a CC License linkje és az esetlegesen végrehajtott módositások feltüntetésre kerülnek. (SID_1) 